\title{
BATS AND MINES: EVALUATING TOWNSEND’S BIG-EARED BAT (CORYNORHINUS TOWNSENDII) MATERNITY COLONY BEHAVIORAL RESPONSE TO GATING
}

\author{
Gabrielle F. Diamond ${ }^{1}$ and Joel M. Diamond ${ }^{2}$
}

\begin{abstract}
With the loss and modification of natural roosting habitat afforded by caves, abandoned mines have assumed increased importance as alternative roosting sites for Townsend's big-eared bats (Corynorhinus townsendii). However, increased human safety concerns have led to accelerated abandoned mine closure programs. To protect roosting sites in mines with significant bat activity, bat-compatible gates are installed that allow continued access to mine workings. Aside from ensuring public safety, these gates provide protection from disturbance to roosting bats. We evaluated the effects of gating on bat flight behavior at maternity colonies in 2 previously gated (control) and 2 ungated (treatment) mines that were gated during this study. We used an infrared video camera to record bat flight behavior at the entrances to each of the 4 study mines for 2 consecutive mornings and a single night each month during the warm season. Entrance (03:00-06:00) and emergence (21:00-24:00) surveys comprised 3 consecutive hours. Overall circling activity increased more than 6 -fold at openings of treatment mines following gating $(P<0.001)$. Crowding during emergence was significantly higher $(P=0.023)$ in newly gated mines than in previously gated mines. Gates affect subadults during the initial-volancy periods, as detected through collisions with the gates. Increased activity of bats and collisions with the gate, which result in bats falling to the ground at mine openings, may amplify vulnerability to predators and increase energetic demands.
\end{abstract}

RESUMEN.-Con la pérdida y/o modificación del hábitat de refugios naturales que proporcionan las cuevas, las minas abandonadas han adquirido mayor importancia como lugares de refugio alternativo para los murciélagos (Corynorhinus townsendii). Sin embargo, se han acelerado los programas de cierre de minas abandonadas para seguridad humana. Para proteger los lugares de anidación en las minas con una significativa actividad de murciélagos, se instalaron puertas compatibles con los murciélagos, lo que permite el acceso continuo a las minas. Además de apoyar la seguridad pública, estas puertas proporcionan protección para los murciélagos. Evaluamos los efectos de las puertas en el comportamiento de vuelo de los murciélagos en colonias de maternidad en dos minas previamente cerradas con puertas (control) y dos minas sin puertas (tratamiento) que se cerraron durante el desarrollo de este estudio. Registramos las conductas de vuelo de los murciélagos usando una cámara de video de ondas infrarrojas instalada en la entrada de las minas durante dos mañanas consecutivas y una sola noche, cada mes durante la estación cálida, en cada una de las cuatro minas del estudio. El estudio de la entrada (03:00-06:00) y la salida (21:00-24:00) comprende 3 horas consecutivas. La actividad circular total aumentó $>6$-veces en las aberturas de las minas de tratamiento tras la colocación de las puertas $(P<$ 0.001). El hacinamiento durante la salida fue significativamente más alto $(P=0.023)$ en minas con puertas recién puestas que en minas cuyas puertas se habían colocado con anterioridad. Las puertas tuvieron impacto en las crías durante los períodos de vuelo inicial, detectados por colisiones contra las puertas. El aumento en la actividad de los murciélagos y en las colisiones contra la puerta que resultaban en su caída al suelo en la entrada de las minas podría amplificar la vulnerabilidad a los depredadores y aumentar las demandas energéticas.

Loss and modification of historical roosting habitat is a major factor contributing to putative declines in many bat populations (Tuttle and Taylor 1994, Adams 2003). Consequently, bats may be more dependent on abandoned mines as alternative surrogate roosts to natural caves (Pierson 1989, Brown and Berry 1991, Brown et al. 1993, Sherwin et al. 2000). Abandoned mines serve functions similar to caves by providing suitable and stable roosting microclimates necessary for the survival of many bat species (Tuttle and Taylor 1994, Altenbach and Sherwin 2002). More than half of the bat species found in the United States regularly use abandoned mines as roosts (Tuttle and Taylor 1994, Bogan 2000, Adams 2003). Of the 18 bat species known in Utah, 14 species regularly roost in abandoned mines, including 8 former Category II (increased sensitivity and heightened protection status) species that utilize mines during parts of the year (Hall and Kelson 1981, Zeveloff and Collett 1988, Adams 2003).

\footnotetext{
${ }^{1}$ WestLand Resources, Inc., 4001 E. Paradise Falls Drive, Tucson, AZ 85712. E-mail: gdiamond@westlandresources.com

${ }^{2}$ Arizona Game and Fish Department, Wildlife Contracts Branch, 5000 W. Carefree Highway, Phoenix, AZ 85086.
} 
Townsend's big-eared bat (Corynorhinus townsendii), a cavern roosting obligate, is one of these former Category II species (Brown and Berry 1991, Oliver 2000, Sherwin et al. 2003).

The Townsend's big-eared bat roosts extensively in abandoned underground mines throughout the western United States (Kunz and Martin 1982, Brown and Berry 1991, Oliver 2000, Sherwin et al. 2003). This species ranges from British Columbia in the north to central Mexico in the south and from the Pacific Coast in the west to the Great Plains in the east (Kunz and Martin 1982). It ranges in elevation from sea level to $3300 \mathrm{~m}$, occupying a variety of habitats (Humphrey and Kunz 1976). This species uses abandoned mines as maternity, day, night, and hibernacula roosting habitat (Sherwin et al. 2000, Sherwin et al. 2003), and colonies are composed of up to 200 individuals (Kunz and Martin 1982). Townsend's big-eared bats have a high roost fidelity and appear to utilize the same roosts from year to year (Pearson et al. 1952, Humphrey and Kunz 1976). They are sensitive to human disturbance and have been recorded abandoning roosts following human disturbance (Humphrey and Kunz 1976, Tuttle and Taylor 1994).

Though Townsend's big-eared bats use abandoned mines for a variety of roosting habitats, not all mines provide significant habitat. Mines exhibiting little or no bat sign are excluded and completely sealed to bat use through reclamation. Typically, a "bat compatible" gate is installed on mines that show significant bat use or are utilized by sensitive or endangered bat species (White and Seginak 1987, Tuttle and Taylor 1994, Dalton and Dalton 1995, Navo 2001, O’Shea et al. 2003). These gates are designed to allow continued access to mine workings for roosting bats while excluding human access (White and Seginak 1987, Tuttle and Taylor 1994, Dalton and Dalton 1995, Navo 2001). Various gate designs and materials are utilized and are designed for specific mine openings (White and Seginak 1987, Tuttle and Taylor 1994, Dalton and Dalton 1995, Navo and Krabacher 2005). The primary gate style used in Utah is round Manganal ${ }^{\circledR}$ steel bars, with horizontal bars spaced $10 \mathrm{~cm}$ apart on the bottom twothirds and $14 \mathrm{~cm}$ apart at the top third of the gate (Amodt and Mesch 2002). Determination of reclamation impacts on roosting bat populations is important because management activities are eliminating significant portions of future roosting habitat by closing mines that currently show little or no bat activity.

Few studies have evaluated the impact of gates on bat use patterns, especially with regard to maternity colonies. Two recent studies addressed bat behavioral responses observed during colony emergence at nonmaternity roosts. Spanjer and Fenton (2005) monitored the response of several bat species in prehibernation swarming roosts to "real" and "mock" gates. Real gates were made of angleiron with bar spacing of $14.6 \mathrm{~cm}$, as suggested by the American Cave Construction Association, while mock gates were made of wood with the same bar spacing. The study found elevated levels of circling and avoidance behaviors during emergence activity. However, the increased circling may have been a response to "novel" gates, because most were short-term $(<1$ month) installations. Furthermore, swarming roosts might not experience the impacts as greatly as maternity colonies, which include more-discrete age classes composed of one species. A study by Derusseau and Huntly (2012) monitored the response of several bat species in night roosts before and after closure with angle-iron gates. That study found a decrease in the mean number of bat species and number of individuals entering the year following gating. However, no statistical differences in flight behaviors were observed after gate installation.

Increased flight time caused by greater circling behavior as bats negotiate a gate may be detrimental during certain life cycle stages, primarily during lactation, by straining an already stressed energy budget. Whether gates are the root cause of increased circling behaviors and higher energy expenditure through increased flight time remains unclear. Several factors may account for circling during emergence activity, thus confounding the interpretation of the precise cause. Bats may circle while (1) sampling ambient light and other environmental conditions prior to emergence from roost sites (Twente 1955, Kunz and Martin 1982), (2) feeding within the mine portal, or (3) experiencing crowding pressure as they attempt to emerge through a constricted area (Brigham and Fenton 1985, Twente 1955, Lacki et al. 1993, Speakman and Tallach 1998, Ludlow and Gore 2000). The question remains whether observed circling events are related 
to species-specific behaviors, such as sampling, feeding, or crowding within the mine portal, or whether circling events are a direct response to the gate.

If circling flight behavior is directly related to gating, we would expect the most profound impact to occur when the energy budget is most strained-that is, during reproduction. Studies of other bat species show that energy demands are 2-2.5 times greater for lactating bats than for nonreproductive individuals (McLean and Speakman 1999). This increased need for energy intake during periods of gestation and lactation may be exacerbated by increased energy expenditure due to circling in response to a bat gate.

In order to determine if circling was directly associated with bat gates, we designed a study that isolated the other known causes of circling and focused on the most energetically strained bat life phase. We isolated the other known causes of circling by recording bat behavior during the return to the roost near sunrise (entrance period) rather than during the emergence from the roost at sunset (emergence period). By focusing on the colony return, we control for the 3 postulated causes of circling: environmental sampling, feeding, and crowding pressure. This line of thought was based on 3 assumptions: (1) bats have been outside of the roost and thus have no need to sample environmental conditions; (2) bats have completed feeding and have no need to feed in the opening; and (3) bats are not under crowding pressure to move through a constricted area because bats will be moving into mine hallways. The objective of this study was to determine if bat gates alter flight behavior in the Townsend's big-eared bat, a species that exhibits high roost fidelity at maternity roosts.

\section{StUdy AREA}

In order to determine if bat gates alter flight behavior in Townsend's big-eared bats, we selected 4 study mines known to contain Townsend's big-eared bat maternity colonies. This sample represents half of all such colonies known to exist at this time of this study in Utah (Oliver 2000). In this study, 2 previously gated mines serve as controls and 2 ungated mines that were gated during the study serve as treatment sites. Occupation of the mines by Townsend's big-eared bats was determined by mist netting and internal mine surveys. These maternity colonies consisted of a mean of 84 to 112 individuals (Table 1).

All study mines were located in western Utah. The first gated control mine, "West Dip Complex," was located in the Tushar Mountains, roughly $3 \mathrm{~km}$ south of Ophir, Utah (Table 1). The second gated control mine, "Marysvale Mine," was located in the Antelope Mountains, roughly $32 \mathrm{~km}$ west of Marysvale, Utah (Table 1). The Marysvale Mine has one horizontal opening, was reclaimed with a bat compatible gate in 2000 , and is $26 \mathrm{~m}$ deep, whereas the West Dip Complex had 2 openings (1 horizontal and 1 vertical), was reclaimed in 1998, and is over $39 \mathrm{~m}$ deep. The Marysvale Mine and West Dip Complex were located in the Colorado Plateau and Great Basin ecoregions, respectively (MacMahon 1997). The 2 ungated/newly gated treatment mines were located in the Sheeprock Mountains (64 km southwest of Vernon, UT) in the Great Basin ecoregion, and these mines were gated in summer 2004. The Cherry Creek ungated mines "Cherry Creek HO Complex" and "Cherry Creek IO Complex" served as the before intervention after treatment: ungated during the first field season (2003) and then newly gated prior to the second field season (2004) (Table 1). Cherry Creek HO Complex was gated on all 3 portals (1 horizontal and 2 vertical) beginning 5 August and ending 1 September 2004, and is over $15 \mathrm{~m}$ deep. The Cherry Creek IO Complex was gated on all 3 of its openings ( 2 inclined horizontal and 1 vertical) beginning on 21 July and ending 4 August 2004, and is over 12 m deep.

\section{Methods}

We collected behavioral data at the openings of each abandoned mine roost by using remote monitoring techniques to reduce roost disturbance and potential observer effects on flight behavior (Kerth and Dechmann 2009, Hayes et al. 2009, Kunz et al. 2009). During surveys, all observers vacated the area during data collection, and equipment was installed and removed while the bats were inside the roost. We recorded bat flights during both entrance and emergence activity periods (Swift 1980, Kunz and Anthony 1996, Hoying and Kunz 1998). We conducted surveys for 2 consecutive years during the maternity roosting season using Sony Nightshot ${ }^{\circledR}$ infrared 
video cameras (Model DCR TRV320) and 3-5 supplemental IR lights. This allowed for evaluation of colony response to gates across life phases and temporal periods. Video analysis provided accurate representation of bat behavior around roost openings in the absence of observers (Kerth and Dechmann 2009).

Mine survey sequence was randomized per month. We conducted video surveys during the new moon phase of the lunar cycle to control for ambient lighting conditions at each site. We collected behavioral data over 2 consecutive mornings and a single night at each roost each month (May-July 2003 and May, July-September 2004, respectively). Entrance and emergence surveys comprised 3 consecutive hours of video recordings. We began recording 15 minutes prior to sunset for emergence period surveys and 2 hours presunrise for entrance period. We set video cameras at inconspicuous locations within $20 \mathrm{~m}$ of the mine portal for full view of the mine opening, leaving a 1-m buffer zone on either side. Additional infrared light sources were placed near the mine portal for further illumination.

Entrance period surveys allowed for observation of the peak colony return activity, when bats were returning from nightly foraging bouts (Swift 1980, Kunz and Anthony 1996, Hoying and Kunz 1998). Observation of the mine openings during entrance periods minimized the confounding influences that might inherently increase circling: sampling, feeding, and crowding pressure. Emergence period surveys allowed for observation of peak colony emergence activity just after sunset.

We cataloged flight behaviors at gated control and ungated/newly gated treatment mines while the bat was within a 1-m buffer of the gate or mine opening, classifying each observed behavior into one of 3 categories. Any bat observed at distances greater than the 1-m buffer was assumed to be indifferent to mine presence and not relevant. This buffer allowed for comparison of where the gate would be installed in treatment mines. Behavioral categories consisted of the following: Enter (In), Exit (Out), and Circling. We defined an Enter behavior as a bat proceeding directly through the bat-compatible gate or mine opening to go into the roost. An Exit behavior was when a bat proceeded directly through the bat-compatible gate or mine opening to leave the roost. Circling behavior was defined 
as a bat approaching to within $1 \mathrm{~m}$ on either side of the gate or mine opening but not proceeding into or out of the mine. Spanjer and Fenton (2005) and Derusseau and Huntly (2012) used similar definitions, but they distinguished between circling behaviors (multiple circles near the gates) and fly-retreat behaviors (approach followed by an abrupt change of direction instead of passing through the gate). Our 1-m buffer was designed to provide a quantitative measure of these circling events at the gate. Thus, in this study we combined circling and fly-retreat behaviors.

To evaluate possible effects of crowding pressure, we recorded when $\geq 2$ or $\geq 3$ individuals were observed within $1-\mathrm{m}$ of the mine opening simultaneously. Townsend's big-eared bats are known to minimize use of echolocation when several individuals are present (Twente 1955), presumably to avoid echolocation bounce from other nearby bats. Evaluation of crowding pressure was necessary because of its potential influence on gate negotiation and bat movement through the mine opening. We also noted the number of bat collisions with the gate or mine structure itself.

\section{Analysis}

Analysis of bat behaviors consisted of comparisons of relative bat activity (Enter, Exit, and Circle events) between mines with and without bat-compatible gates. We also compared bat activity between emergence peak and entrance peak behavior to evaluate gate response. All 3 behavioral categories were totaled per survey period to obtain a broader picture of seasonal behavioral patterns. In addition, we compared Circling event totals with combined Enter and Exit event totals (circling ratio) for gated and ungated mine conditions to determine if bat behaviors were skewed towards any treatment. This allowed us to evaluate circling details for each discrete event to determine which measure best captures colony movement patterns. We conducted a detailed comparison of peak entrance behaviors at gated and ungated mine conditions over the entire season to evaluate possible differences between mines and seasonal life stages. One-way ANOVAs and Fisher's LSD tests $(P<0.05)$ were used to compare these circling ratios between gated and ungated conditions, as well as across bat life stages (gravid, lactating, and initial-volancy). Statisti- cal computations were conducted using $\mathrm{SAS}^{\circledR}$ software (JMP; SAS Institute, Inc. 2002).

Evaluations of potential crowding pressure were based on comparisons between mines under all conditions during both field seasons. Analyses consisted of $t$ tests comparing the time (minutes) that $\geq 2$ and $\geq 3$ bats were present within $1 \mathrm{~m}$ of the mine portal during both emergence and entrance peak activity. The percentage of time that $\geq 2$ and $\geq 3$ bats were within or near the mine opening was evaluated, with total activity ranging from observation of the first bat to observation of the last bat during peak activity. The presence of 2 or more bats was used to evaluate crowding impact, but this parameter may be biased by paired "coaxing" events observed within maternity colonies (O'Shea and Vaughan 1977, Spanjer and Fenton 2005, Derusseau and Huntly 2012). To reduce this possible bias, we also analyzed the presence of $\geq 3$ bats within the portal to assess potential crowding pressure. This was compared across gated and ungated mine conditions.

\section{REsults}

We recorded and analyzed a total of 83 video hours (69 entrance and 14 emergence) for the first season and 123 video hours, 24 of which included newly gated activity, for the second season (87 entrance and 36 emergence). In total, we analyzed 206 video hours of Townsend's big-eared bat behavior at maternity roost openings. The Marysvale Mine had the highest number of bat Enter and Exit events, followed by the West Dip Complex, Cherry Creek IO Complex, and Cherry Creek HO Complex, in decreasing order (Fig. 1). Circling was significantly $(F=7.03, P=0.023)$ higher during the emergence period. Therefore, our circling behavior analyses included only entrance behavior to reduce effects that may mask potential gate responses (sampling, feeding, or crowding). However, we compared crowding pressure and bat-gate collisions across the entrance and emergence peaks.

\section{Circling Behavior}

The circling ratio differed significantly between gated, ungated, and newly gated mine conditions $(F=145, P<0.001)$ (Fig. 1). The circling ratio in the newly gated Cherry Creek HO Complex fluctuated around 4:1 following 


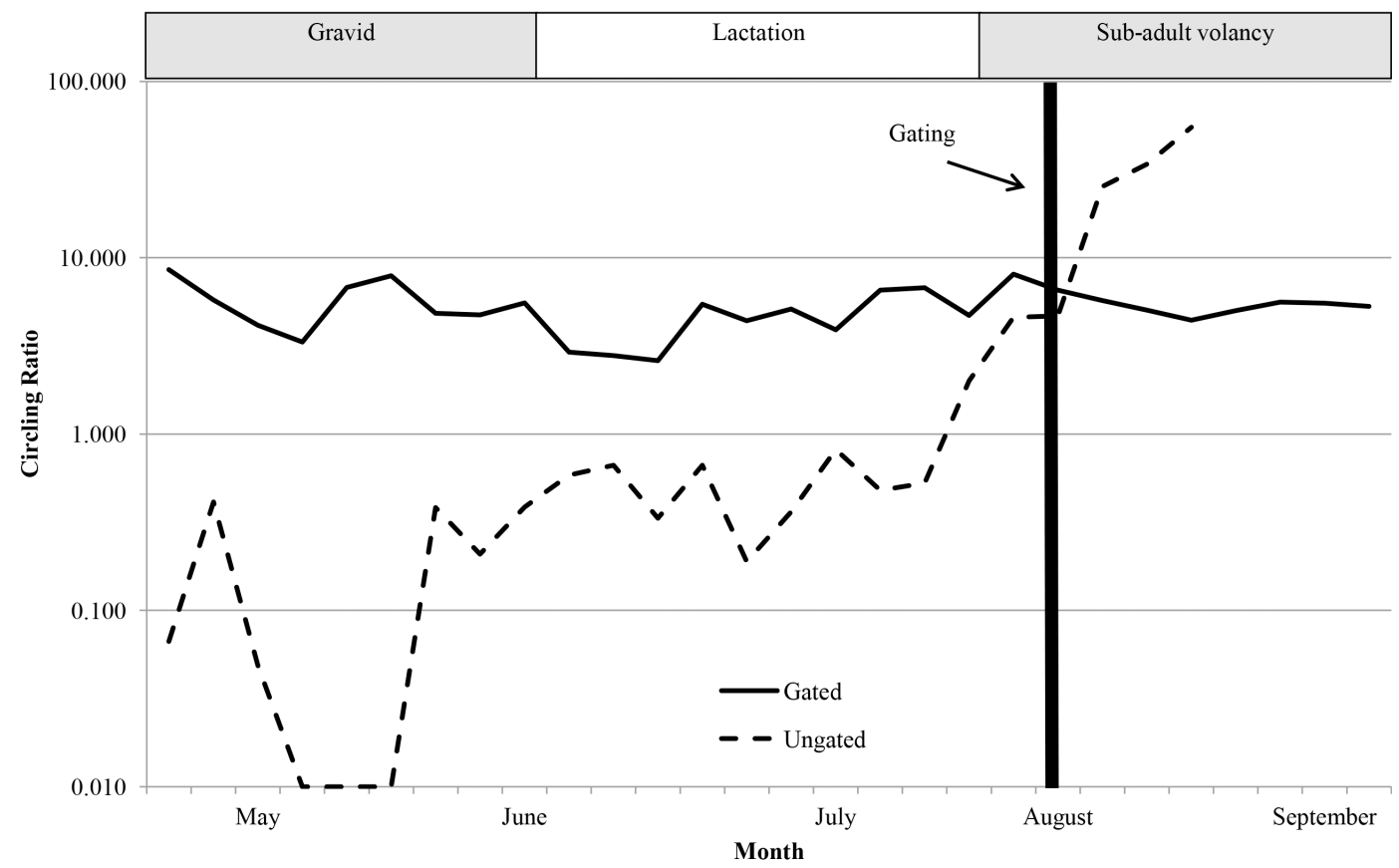

Fig. 1. Ratio of Circling event totals to combined Enter and Exit events at study mines. Gates were on the control mines during the entire study. Treatment mines were ungated during the first year, and gates were installed on ungated treatment mines beginning in July of the second year.

gate installation, whereas the circling ratio in the newly gated Cherry Creek IO Complex exceeded 25:1. These mines, when ungated, showed no statistical difference in circling ratios $(P=0.393)$, with ratios of $0.3: 1$ and 0.5:1. Gated control mines Marysvale Mine and West Dip Complex also showed no difference in circling behaviors $(P=0.250)$ throughout the study, exhibiting ratios of $7: 1$ and $6: 1$, respectively, across survey years. The circling ratio averaged $0.3: 1$ in ungated mines, 5.3:1 in gated mines, and 21.4:1 in newly gated mines. The circling ratio within gating treatments did not differ significantly $(F=2.75, P=0.069)$ across life stages (Fig. $1)$. Ungated mines had circling ratios that varied from $0: 1$ to $0.8: 1$, while gated and newly gated mines had circling ratios that varied from $8.6: 1$ to $2.6: 1$ and $2.0: 1$ to $55.0: 1$, respectively. The number of combined Exit and Entrance events did not differ significantly $(F=0.76, P=0.393)$ from the number of Circling events in the ungated mines, whereas Circling events were significantly higher than combined Entrance and Exit events in both the gated $(F=31.01, P<$
$0.0001)$ and newly gated mines $(F=37.53$, $P<0.0001)$.

\section{Crowding Pressure}

We detected multiple bats in the portal of the gated and newly gated mines more frequently than in the ungated mines. Crowding increased most during emergence peak, suggesting differential gate effects on mine portal use $(P=$ 0.023; Fig. 2). In gated control mines, $\geq 2$ bats occurred more frequently $(30 \%-42 \%)$ than $\geq 3$ bats $(10 \%-44 \%)$ over the total activity period. Newly gated treatment mines showed similar trends, with $\geq 2$ bats observed most frequently. The Cherry Creek HO Complex when ungated, exhibited $\geq 2$ bats $8 \%$ of the time but had no occurrence of $\geq 3$ bats. After gating, the percentage increased considerably to $\geq 2$ bats $20 \%$ of the time and $\geq 3$ bats in the portal $2 \%$ of the time. Cherry Creek IO Complex, while ungated, had $\geq 2$ bats $3 \%-7 \%$ of the time, jumping to $\geq 3$ bats $22 \%-32 \%$ of the time after gate installation.

\section{Bat-Gate Collisions}

Actual bat-gate collisions were observed during the latter parts of the reproductive 


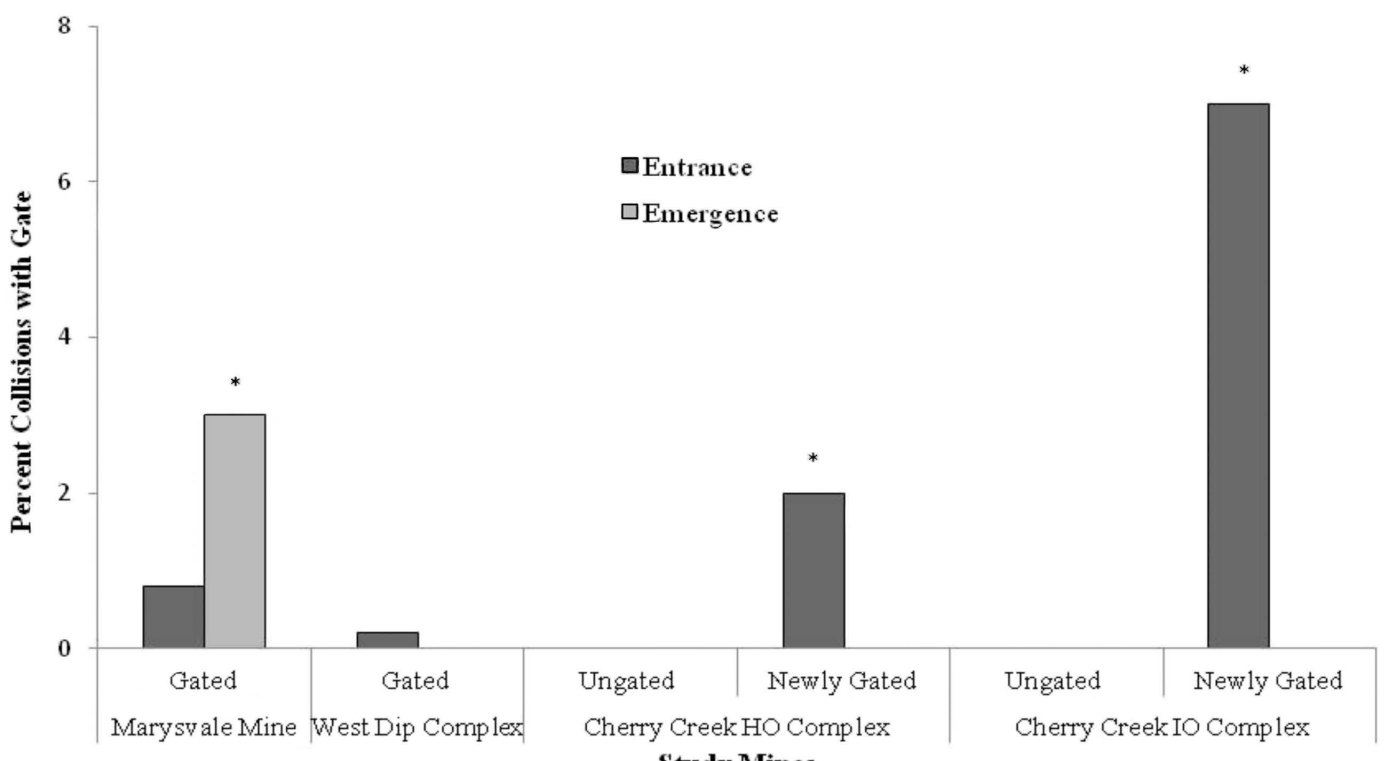

Fig. 2. Percentage (fraction of total Exit and Enter events) of bat-gate collisions during entrance and emergence activity as determined by infrared video camera sequences. All observed gate collisions occurred in July during subadult initialvolancy periods. An asterisk $(*)$ indicates significance $(P<0.001)$.

season during the subadult initial-volancy periods. The frequency of gate contact varied between mines and time of seasons. We observed gate collisions in all gated mines, including newly gated treatment mines. The number of collisions was highest in the Marysvale Mine, with 50 total impacts observed; Cherry Creek IO Complex had 17 total collisions, whereas the remaining mines experienced $<5$ each. The percentage of actual collisions per total nightly Enter and Exit events was higher in Cherry Creek IO Complex after gating (Fig. 2). Although highest in actual number of impacts, Marysvale Mine was second, with percentage of collisions making up 3\% of its activity. Cherry Creek HO Complex experienced gate collisions making up $2 \%$ of its activity (Fig. 2). The majority of observed impacts occurred during entrance peak activity (Fig. 2). Gate collisions resulted in bats falling to the ground $11 \%$ of the time, and bats were able to fly away in all incidences.

\section{Discussion}

\section{Circling Behavior}

Townsend's big-eared bat maternity colony response to gating was immediate but ephemeral. The maternity colony inside the Cherry
Creek IO Complex treatment mine relocated to a small ungated mine $30 \mathrm{~m}$ away during gate installation. This alternative mine appeared to be unsuitable for maternity colony occupation due to its small size (5 $\mathrm{m}$ depth) and hence limited protection from human and nonhuman disturbance, unstable microclimate, and lack of dark areas. The colony stayed in this surrogate mine for 3 days before returning to the original maternity roost. Short-term roost abandonment was not detected in the Cherry Creek HO Complex. While short-term relocation was observed in one site, maternity colonies were present within all study mines through the end of the roosting period.

Townsend's big-eared bat maternity colonies appeared to show behavioral responses to gating of abandoned mines, as indicated by increases in circling activity around the mine openings. Circling behaviors intensified with the installation of bat-compatible gates, while existing gated control mines showed no difference in the amount of time spent circling during the same period. Variations in the amount of circling were apparent at both the individual and colony level. Some individual bats exhibited no circling behavior, while others circled $>27$ times before moving through the 
opening. The bats in the treatment mine Cherry Creek IO Complex exhibited more circling than those in the Cherry Creek HO Complex. These treatment mines showed no difference in circling before gating.

Increases in circling behaviors associated with bat-compatible gates may stress a bat's already stretched energy budget during reproductive periods. Each circling event takes twice the time of an exit or entrance, thus requiring twice the energy expenditure. Because bats must spend more flight time to move through gated mines, the amount of foraging time available to obtain energy is reduced. A study of the Ozark big-eared bat (C. townsendii ingens) suggests that during periods of high energetic demand (reproductive period), the output may be offset by heightened seasonal prey abundance (Clark et al. 2002). Therefore, impacted colonies may be able to forage more effectively, and thus increased energetic demands incurred through longer roost flight may become negligible.

Spanjer and Fenton (2005) found differences in fly-retreat and circling behavior in the presence of smaller gates $\left(<9.5 \mathrm{~m}^{2}\right)$, and these differences were present in sites that had been gated for over 10 years when compared to ungated sites. Derusseau and Huntly (2012) found no statistical difference in flight behaviors in night roosts, but they did detect decreases in the mean number of species and individuals entering gated sites. Unlike our study, their evaluations occurred at roosts, which were being used by multiple species and which likely had lower fidelity than maternity colonies.

\section{Crowding Pressure}

Comparisons of peak emergence and entrance periods yielded significant differences, with higher amounts of circling occurring during colony emergence. These results suggest that crowding may influence colony emergence behaviors more strongly than entrance activity. Bats are forced through a restricted space when attempting to exit nightly. These same conditions are not present during entrance activity, as bats are moving into the confines of the mine tunnel. Bullock et al. (1987) proposed that emerging colonies experience bottleneck effects leading to clustering as individuals move through confined roost openings. Others have suggested that bats naturally cluster during emergence to transfer information between colony members (Twente 1955, Wilkinson 1992, Clark et al. 2002) or as a means of predator swamping (Speakman et al. 1995). In the case of gating, it is likely that gates impose bottleneck conditions independent of opening size, because bats must negotiate the bars and may need to specifically orient or maneuver themselves to pass through. Increases in collisions with gates also suggested crowding pressure. During the period of subadult volancy, gate negotiation time was lengthened, likely due to crowding of inexperienced flyers within a confined area. Given that Townsend's big-eared bat maternity colonies generally do not exceed several hundred individuals, this crowding in response to gating may be negligible.

Spanjer and Fenton (2005) did not directly evaluate tandem or paired flights in their study. However, they did find increased flight behavior in the presence of smaller gates, which suggests that crowding pressures are more prevalent as roosting bats attempt to move through the confined space. Derusseau and Huntly (2012) found an increase in tandem flight after gating at night roosts. This is similar to our findings of increased occurrence of $\geq 2$ bats simultaneously near the gate during emergence.

\section{Bat-Gate Collisions}

The number of gate collisions increased during the subadult volancy period, indicating that the lack of flight experience is likely related to gate navigation in this species. We observed no collisions with mine walls or ceilings in the absence of gates. This suggests that collisions were related specifically to the gate. Subadults are naive each year and must therefore learn to navigate the gate for the first time. If the gate reduces fitness through direct collisions, then subadult survival could be negatively impacted.

Frequency of gate collisions varied between colonies. The Cherry Creek IO Complex treatment mine clearly showed more collisions after gating. This suggests that colonies respond to gates differently. Consequently, gating may influence colonies in newly gated mines unpredictably. Colonies in older ( $>6$-year-old) gated mines also responded uniquely to gates. The colony at the Marysvale gated control mine exhibited high numbers of collisions. It is 
not clear whether these collisions are strictly crowding related or a result of flight inexperience. Collisions have been observed in other species during periods of subadult volancy. A study of a pallid bat (Antrozous pallidus; similar size, shape, and general anatomy to Townsend's big-eared bat) maternity roost recorded several occasions in which bats collided with the walls of the roost and fell to the ground (O'Shea and Vaughan 1977).

A recent study of prehibernation swarming roosts suggests that collisions were not related strictly to maternity roosts and Townsend's big-eared bats. Spanjer and Fenton (2005) studied 16 gated and 12 ungated sites used by at least 6 species, including Townsend's big-eared bats. They observed collisions at real and mock gated roosts. In fact, these collisions made up $2 \%$ of the total activity within swarming roosts. This is similar to our findings, with collisions making up $2 \%-7 \%$ of the portal activity depending on the mine. The study by Derusseau and Huntly (2012), which evaluated 5 gated and 5 ungated night roosts, did not mention collisions after gating.

\section{Predation}

Increases in colony flight time due to circling in gated openings and collisions with gate structures may increase the vulnerability of bats because roosts may become more conspicuous to predators. As the colony is forced through a crowded opening congested with individuals, it is inevitable that overall passage will slow. Although no predation events were observed in this study, potential predatorsGreat Basin western rattlesnakes (Crotalus oreganus lutosus)—were observed only at gated mines approximately $10 \%$ of the time. These predators may not typically prey on bats, but can opportunistically capture bats that fall to the ground after a gate collision. This is contrary to Spanjer and Fenton's (2005) study of swarming roosts, in which no predators were observed near study mines. This difference may be due to the presence of researchers stationed near the gates to record activity and their use of lanterns with red cellophane to illuminate the gates, whereas this study incorporated remote observations through video images with infrared lighting. Derusseau and Huntly's (2012) study of night roosts did not mention predators near the mines or whether observers remained in the area. Predation increases during subadult volancy periods in other species (O’Shea and Vaughan 1977); thus, our observations may reflect this amplified pressure. The impact of predators may be great on population growth, as many bat species have low reproductive rates (Kunz 1982). This aspect warrants further evaluation.

\section{MANAGEMENT IMPLICATIONS}

Townsend's big-eared bats may be capable of altering other aspects of their behavior to compensate for longer flight periods imposed by gate navigation. Several possibilities exist: reduction of night roosting, increased foraging time, or use of daily torpor. Townsend's bigeared bats may have the ability to counteract gating effects behaviorally, as demonstrated in studies of similar species. Whatever the case, affected bats do not permanently abandon the gated mine roost once gates are installed. This suggests that this species is able to cope with the bat-compatible gate in both the short term (2-year duration of this study) and the long term (West Dip Complex was gated in 1998).

The costs of bat gates to maternity colonies may be outweighed by the protective benefit of the bat-compatible gates. Townsend's bigeared bats are sensitive to human disturbance and will abandon roosts when disturbed (Pearson et al. 1952, Twente 1955, Tuttle and Taylor 1994). Maternity colonies and hibernation roosts are especially vulnerable to roost disturbance, which can have cascading impacts throughout the entire population. Bat gates undoubtedly reduce direct disturbance to these critical roost types by limiting human access. While increases in circling and collisions and potential increases in predation pressures occur after gating, roost protection may outweigh these risks. Spanjer and Fenton (2005) suggest that higher energetic expenditures due to increases in flight time are the real cost to bats, rather than collisions and predation. Further long-term research is needed to evaluate overall impacts on colony survivorship and reproduction to develop a clearer picture of reclamation influences.

The debate continues about the role of bat gates as a management tool for the protection of sensitive bat species. Townsend's big-eared bat maternity colonies respond behaviorally to gates, but current evidence suggests that 
populations persist at least in the short term. These data do suggest that caution should be exercised when employing this management technique. Long-term evaluations of this tool must continue to further improve gate design and to interpret its effects on other bat species. Population change may require several generations to become apparent, because Townsend's big-eared bats are a long-lived and slow-reproducing species (Kunz and Martin 1982, Sherwin and Altenbach 2002).

Only one gate design was evaluated in this study, whereas several types and variations are being used worldwide. A study by White and Seginak (1987) that compared major gate types indicated highest use through round-bar gates in contrast to angle-iron or funnel-type gate designs. Big-eared bats were shown to select round-bar designs over others, suggesting a species-specific response to closures. The round-bar gate design employed in Utah incorporates characteristics that facilitate bat movement, specifically greater spacing between bars near the top third of the gate.

Although this study suggests that bat gates may negatively impact targeted populations, these impacts may be outweighed by positive effects, such as prevention of roost disturbance to reproductive females. The extent of gating influences on roosting colonies may vary with location and human disturbance levels; thus, evaluation on a broader scale is essential to understanding the effects of gates. The role of gating as a management tool requires continued research, and various gate designs should be evaluated, as species have shown a variety of responses (Sherwin and Altenbach 2002).

\section{ACKNOWLEDGMENTS}

We thank Dr. Michael Wolfe, Dr. James A. MacMahon, and Dr. Karen H. Beard of Utah State University for support, advice, and review of this study. We also thank Dr. Kate W. Grandison of Southern Utah University for support, guidance, and use of equipment. Thanks to Mark Mesch, Utah Division of Oil, Gas and Mining: Abandoned Mine Reclamation Program Director, for advice and use of a field vehicle and personnel. Thank you to The Utah Chapter of The Wildlife Society for a small grant, which was used to obtain portions of the equipment.

\section{Literature Cited}

ADAMs, R.A. 2003. Bats of the Rocky Mountain West: natural history, ecology, and conservation. University Press of Colorado, Boulder, CO. 302 pp.

Altenbach, J.S., and R.E. Sherwin. 2002. Importance of protecting mines. Bat gate design: a technical interactive forum. Office of Surface Mining Reclamation and Enforcement, Albuquerque, New Mexico, NM. Available from: http://www.mcrcc.osmre.gov

Amodt, L.A., AND M.R. Mesch. 2002. Round bar manganal ${ }^{\circledR}$ steel “jail bar" bat gate. Pages 232-252 in K.C. Vories and D. Throgmorton, editors, Proceedings of the Bat Gate Design Forum, March 4-6, Austin, Texas.

Bogan, M.A. 2000. Western bats and mining. Pages 41-50 in Proceedings of Bat Conservation and Mining: a technical interactive forum held November 14-16, 2000, Airport Hilton, St. Louis, Missouri. U.S. Department of the Interior, Office of Surface Mining, and Coal Research Center, Southern Illinois University, Carbondale, IL.

Brigham, R.M., and M.B. Fenton. 1985. The influence of roost closure on the roosting and foraging behavior of Eptesicus fuscus (Chiroptera: Vespertilionidae). Canadian Journal of Zoology 64:1128-1133.

Brown, P.E., AND R.D. BERRY. 1991. Bats: habitat, impacts and mitigation. Pages 26-30 in R.D. Comer, P.R. Davis, S.Q. Foster, C.V. Grant, S. Rush, O. Thorne II, and J. Todd, editors, Proceedings of the Thorne Ecological Institute: issues and technology in the management of impacted wildlife. Thorne Ecological Institute, Snowmass, CO.

Brown, P.E., R.D. Berry, and C. Brown. 1993. Bats and mines: finding solutions. Bats 11(2):12-13.

Bullock, D.J., B.A. Combes, and L.A. Eales. 1987. Analysis of the timing and pattern of emergence of the pipistrelle bat (Pipistrellus pipistrellus). Journal of Zoology 211:267-274.

Clark, B.S., B.K. Clark, AND D.M. Leslie JR. 2002. Seasonal variation in activity patterns of the endangered Ozark big-eared bat (Corynorhinus townsendii ingens). Journal of Mammalogy 83:590-598.

Dalton, D.C., AND V.M. Dalton. 1995. Mine closure methods including a recommended gate design. Pages 130-135 in R.B. Riddle, editor, Inactive mines as bat habitat: guidelines for research survey and monitoring, and mine management in Nevada. Biological Resources Research Center, University of Nevada, Reno, NV.

Derusseau, S.N., AND N.J. Huntly. 2012. Effects of gates on the nighttime use of mines by bats in northern Idaho. Northwestern Naturalist 93:60-66.

Hall, E.R., AND K.R. Kelson. 1981. Mammals of North America. 2nd edition. John Wiley \& Sons, New York, NY.

Hayes, J.P., H.K. Ober, AND R.E. Sherwin. 2009. Survey and monitoring of bats. In: T.H. Kunz and S. Parsons, editors, Ecological and behavioral methods for the study of bats. 2nd edition. Johns Hopkins University Press, Baltimore, MD.

Hoying, K.M., AND T.H. Kunz. 1998. Variation in size at birth and post-natal growth in the eastern pipistrelle bat (Pipistrellus subflavus) (Chiroptera: Vespertilionidae). Journal of Zoology (London) 245:15-27.

HumphreY, S.R., AND T.H. KunZ. 1976. Ecology of a Pleistocene relict, the western big-eared bat (Plecotus 
townsendii), in the southern Great Plains. Journal of Mammalogy 57:470-494.

Kerth, G., and D.K.N. Dechmann. 2009. Field-based observations and experimental studies of bat behavior. In: T.H. Kunz and S. Parsons, editors, Ecological and behavioral methods for the study of bats. 2nd edition. Johns Hopkins University Press, Baltimore, MD.

KunZ, T.H. 1982. Ecology of bats. Plenum, New York, NY.

KunZ, T.H., AND E.L.P. ANTHONY. 1996. Variation in nightly emergence behavior in the little brown bat, Myotis lucifugus (Chiroptera: Vespertilionidae). Pages 225-236 in H.H. Genoways and R.J. Baker, editors, Contributions in mammalogy: a memorial volume honoring Dr. J. Knox Jones, Jr. Texas Tech University Press, Lubbock, TX.

Kunz, T.H., M. BetKe, N.I. Hristov, and M.J. Vonhof. 2009. Methods for assessing colony size, population size, and relative abundance of bats. T.H. Kunz and $\mathrm{S}$. Parsons, editors, in Ecological and behavioral methods for the study of bats. 2nd edition. Johns Hopkins University Press, Baltimore, MD.

KunZ, T.H., AND R.A. Martin. 1982. Plecotus townsendii. Mammalian Species 175:1-6.

Lacki, M.J., M.D. Adam, and L.G. Shoemaker. 1993. Observations on seasonal cycles, population patterns and roost selection in summer colonies of Plecotus townsendii virginianus in Kentucky. American Midland Naturalist 131:34-42.

LudLOw, M.E., AND J.A. GORE. 2000. Effects of a cave gate on emergence patterns of colonial bats. Wildlife Society Bulletin 28:191-196.

MacMahon, J.A. 1997. National Audubon Society Nature Guides. Deserts. 1st edition. Chanticleer Press, New York, NY.

McClean, J.A., and J.R. Speakman. 1999. Energy budgets of lactating and non-reproductive brown longeared bats (Plecotus auritus) suggest females use compensation in lactation. Functional Ecology 13: 360-372.

NAvo, K.W. 2001. The survey and evaluation of abandoned mines for bat roosts in the west: guidelines for natural resource managers. Proceedings of the Denver Museum of Nature \& Science 4(2):1-12.

Navo, K.W., and P. Krabacher. 2005. The use of gates at abandoned mines in Colorado. Bat Research News 46:108.

Oliver, G.V. 2000. The bats of Utah: a literature review. Publication number 00-14, Utah Division of Wildlife Resources-Utah National Heritage Program, Salt Lake City, UT.

O'Shea, T.H., and T.A. Vaughan. 1977. Nocturnal and seasonal activities of the pallid bat, Antrozous pallidus. Journal of Mammalogy 58:269-284.

O’Shea, T.J., M.A. Bogan, and L.E. Ellison. 2003. Monitoring trends in bat populations of the United States and territories: status of the science and recommendations for the future. Wildlife Society Bulletin 31:16-29.

Pearson, O.P., M.R. Koford, and A.K. Pearson. 1952. Reproduction of the lump-nosed bat (Corynorhinus rafinesquii). Journal of Mammalogy 33:273-320.

Pierson, E.D. 1989. Help for Townsend's big-eared bats in California. Bats 7(1):5-8.

SAS Institute, InC. 2002. JMP, the statistical discovery software, version 5. SAS Institute, Inc., Cary, NC.

Sherwin, R.E., AND J.S. AltenbaCh. 2002. The responses of bats to gates. Pages 388-395 in K.C. Vories and D. Throgmorton, editors, Bat gate design: a technical interactive forum. 4-6 March 2002. Austin, TX.

Sherwin, R.E., W.L. Gannon, and J.S. Altenbach. 2003. Managing complex systems simply: understanding inherent variation in the use of roosts by Townsend's big-eared bat. Wildlife Society Bulletin 3:62-72.

Sherwin, R.E., D. Strickland, and D.S. Rogers. 2000. Roosting affinities of Townsend's big-eared bats (Corynorhinus townsendii) in northern Utah. Journal of Mammalogy 81:939-947.

Spanjer, G.R., and M.B. Fenton. 2005. Behavioral responses of bats to gates at caves and mines. Wildlife Society Bulletin 33:1101-1112.

Speakman, J.R., R.E. Stone, and J.E. Kerslake. 1995. Temporal patterns in the emergence behavior of pipistrelle bats, Pipistrellus pipistrellus, from maternity colonies are consistent with anti-predator behavior. Animal Behavior 50:1147-1156.

Speakman, J.R., and N. Tallach. 1998. Do emerging pipistrelle bats loose control of their timing due to 'crowd pressure'? Journal of Zoology 246:445-448.

SwIFT, S.M. 1980. Activity patterns of pipistrelle bats (Pipistrellus pipistrellus) in northeast Scotland. Journal of Zoology 190:285-295.

Tuttle, M.D., AND D.A.R. TaYlor. 1994. Bats and mines. Resource publication no. 3, Bat Conservation International, Inc.

Twente, J.W., JR. 1955. Some aspects of habitat selection and other behavior of cavern-dwelling bats. Ecology 36:706-732.

White, D.H., AND J.T. SEgINAK. 1987. Cave gate designs for use in protecting endangered bats. Wildlife Society Bulletin 15:445-449.

WiLKInSON, G.S. 1992. Information transfer at evening bat colonies. Animal Behavior 44:501-518.

Zeveloff, S.I., and F.R. Collett. 1988. Mammals of the Intermountain West. 1st edition. University of Utah, Salt Lake City, UT.

Received 23 September 2013 Accepted 18 August 2014 